\title{
PENERAPAN ASAS HUKUM DALAM PENYELESAIAN PERKARA DI PENGADILAN AGAMA
}

\author{
Rosdalina, Edi Gunawan \\ Institut Agama Islam Negeri Manado | Jl. Manguni, Malendeng, Tingkala, Kota \\ Manado, Sulawesi Utara \\ edigunawan@iain-manado.ac.id
}

\begin{abstract}
Court is a judicial institution, which has the authority to settle cases between the parties. In carrying out these duties and authorities, this institution adheres to the simple, quick, and low cost principles as mandated in the judicial power law. The application of simple and quick principles in terms of making lawsuits or petitions is as practiced in a Religious Court of Manado. One of the elements that helps is the existence of Legal Aid Post (POSBAKUM) based in the Religious Court of Manado. As for the settlement of cases, the application of the principle has not been implemented properly. This is because the parties are less seriously coming at the trial that has been determined and the judges often postpone the hearing by several argumentations. The cost of litigation in a Religious Court of Manado is determined based on the radius or distance of the domiciled party territory. If the Plaintiff is incompetent and has a poor card, it may incur a court fee waiver.
\end{abstract}

Keywords: Application, principle, case, Religious Court

\begin{abstract}
Abstrak: Pengadilan merupakan lembaga yudikatif yang memiliki kewenangan menyelesaikan perkara antar para pihak. Dalam menjalankan tugas dan kewenangan tersebut, lembaga ini menganut asas sederhana, cepat dan biaya ringan sebagaimana diamanatkan dalam undang-undang kekuasaan kehakiman. Penerapan asas sederhana dan cepat dalam hal pembuatan gugatan ataupun permohonan di Pengadilan Agama yang diteliti yaitu Pengadilan Agama Manado dapat dilaksanakan dengan baik. Salah satu unsur yang membantu adalah adanya Pos Bantuan Hukum (POSBAKUM) yang berkantor di Pengadilan Agama Manado. Adapun dalam hal penyelesaian perkara, penerapan asas tersebut belum dilaksanakan dengan baik. Hal ini disebabkan karena para pihak kurang bersungguhsungguh hadir pada persidangan yang telah ditentukan dan majelis hakim sering menunda sidang dengan alasan dinas luar atau cuti.
\end{abstract}


Adapun biaya berperkara di Pengadilan Agama Manado ditentukan berdasarkan radius atau jarak wilayah pihak berdomisili. Jika Penggugat termasuk masyarakat tidak mampu dan memiliki kartu miskin, maka dapat dikenakan pembebasan biaya perkara.

Kata Kunci: Penerapan, asas, perkara, Pengadilan Agama

\section{Pendahuluan}

Pengadilan merupakan salah satu badan peradilan di bawah naungan Mahkamah Agung yang memiliki tugas dan fungsi menyelesaikan perkara yang diajukan oleh para pihak. Lingkungan peradilan tersebut diatur dalam Pasal 10 ayat (2) Undang-Undang Nomor 4 Tahun 2004 tentang Kekuasaan Kehakiman bahwa badan peradilan di bawah Mahkamah Agung meliputi badan peradilan dalam lingkungan Peradilan Umum, Peradilan Agama, Peradilan Militer dan Peradilan Tata Usaha Negara.

Sebagai salah satu badan peradilan di bawah Mahkamah Agung, Peradilan Agama bertugas dan berwenang memeriksa, memutus dan menyelesaikan perkara di tingkat pertama antara orang-orang yang beragama Islam di bidang perkawinan, waris, wasiat, hibah, wakaf, zakat, infak, shadaqah dan ekonomi syari'ah. ${ }^{1}$

Penyelesaian perkara perkawinan, waris, wasiat, hibah, wakaf, zakat, infak, shadaqah dan ekonomi syari'ah yang merupakan kompetensi absolut Pengadilan Agama berpedoman pada Pasal 5 ayat (2) Undang-Undang Nomor 4 Tahun 2004 tentang Kekuasaan Kehakiman yang menyebutkan bahwa pengadilan membantu pencari keadilan dan berusaha mengatasi segala hambatan dan rintangan untuk dapat tercapainya peradilan yang sederhana, cepat dan biaya ringan. Hal ini menunjukkan bahwa peradilan memiliki peran yang sangat penting dalam membantu pencari keadilan untuk mengatasi masalah yang dihadapinya.

Untuk menyelesaikan konflik kepentingan yang sering terjadi dalam masyarakat dengan baik, secara teratur demi terpeliharanya

' Lihat Pasal 49 Undang-Undang Nomor 50 Tahun 2009 Tentang Peradilan Agama. 
ketertiban yang berkedamaian di dalam masyarakat, diperlukan adanya suatu institusi (kelembagaan) khusus yang mampu menyelesaikan masalah secara tidak memihak (imparsial) dengan berlandaskan patokan-patokan yang berlaku secara objektif. ${ }^{2}$

Van Apeldoorn sering menyamakan hukum dengan undangundang. Padahal, kita tidak melihat hukum di dalam undangundang, akan tetapi di dalamnya terlihat sesuatu tentang hukum, karena apa yang terlihat di dalam undang-undang, pada umumnya (tidak selamanya) hukum. ${ }^{3}$ Van Apeldoorn tidak hanya melihat konsep hukum itu tampak pada sifat jabatan seorang hakim, yaitu mengatur dan memaksa, tetapi konsep hukum senantiasa berkembang, bergerak karena pengadilan selalu membentuk hukum baru. Kalimat terakhir inilah menunjukkan bahwa Van Apeldoorn mengakui putusan pengadilan sebagai sumber hukum selain undang-undang.

Sebagai sumber hukum selain undang-undang, maka putusan pengadilan perlu memberikan keadilan dalam bentuk putusan yang seadil-adilnya kepada pencari keadilan dan menerapkan asas sederhana, cepat dan biaya ringan dalam proses penyelesaian perkara. Sistem kekuasaan kehakiman Indonesia berdasarkan Undang-Undang Nomor 48 Tahun 2009 telah mengakui pandangan aliran Sociological Jurisprudence, yang terbukti dengan dimasukkannya ketentuan Pasal 5 ayat (1) yang berbunyi sebagai berikut :

"Hakim dan hakim konstitusi wajib menggali, mengikuti, dan memahami nilai-nilai hukum dan rasa keadilan yang hidup dalam masyarakat". ${ }^{4}$

Bunyi Pasal di atas mengandung aspek filosofis, sosiologis, teleologis dan aspek yuridis. Aspek filosofis mengandung makna bahwa fungsi dan peranan hakim yang dikehendaki oleh undang-

\footnotetext{
${ }^{2}$ Lili Rasjidi dan Ira Thania Rasjidi, Dasar-Dasar Filsafat dan Teori Hukum, (Bandung: Citra Aditya Bakti, 2007), 93.

${ }^{3}$ Romli Atmasasmita, Teori Hukum Integratif-Rekonstruksi Terhadap Teori Hukum Pembangunan dan Teori Hukum Progresif, (Yogyakarta: Genta Publishing, 2012), 17.

${ }^{4}$ Romli Atmasasmita, Teori Hukum Integrarif, 39.
} 
undang adalah legislator's judge. Aspek sosiologis mengandung makna bahwa hakim harus peka dan tanggap terhadap nilai keadilan yang berkembang dalam masyarakat. Aspek teleologis mengandung makna bahwa hakim harus memahami tujuan pembentukan suatu undang-undang dan tujuan umum dari hukum yaitu memelihara ketertiban, kepastian hukum dan keadilan serta kemanfaatan dalam satu rangkaian sistematis yang sepatutnya tercermin di dalam putusan pengadilan. Sedangkan aspek yuridis mengandung makna dasar putusan hakim harus diletakkan pada undang-undang (hukum tertulis). Keempat aspek yang terkandung dalam Pasal 5 di atas perlu dipahami oleh hakim untuk mencapai cara berpikir paripurna dalam memeriksa dan memutus suatu perkara.

Hakim dalam tugasnya menerima, memeriksa, menyelesaikan dan memutus perkara hendaknya berpijak pada nilai-nilai kebenaran dan keadilan serta menjunjung tinggi asas peradilan yaitu asas sederhana, cepat dan biaya ringan. Penerapan asas tersebut sangat penting untuk diperhatikan sebagai bentuk pertanggungjawaban hakim dalam kedudukannya sebagai penegak hukum dalam memberikan rasa keadilan kepada pencari keadilan.

Kenyataan di lapangan menunjukkan bahwa dewasa ini sebagian masyarakat sebagai pencari keadilan tidak menemukan dan mencapai keadilan di lembaga peradilan. Keadilan hanya dapat dirasakan oleh orang-orang yang 'berduit dan memiliki kekuasaan'. Proses peradilan yang katanya menjunjung tinggi asas sederhana, cepat dan biaya ringan hanyalah menjadi simbol, slogan dan bingkai peradilan yang sering dikumandangkan oleh penegak hukum. Proses pelayanan dan penyelesaian perkara di pengadilan membutuhkan waktu dan biaya yang sulit dijangkau oleh masyarakat. Bahkan mereka yang tidak mampu, perkaranya baru dapat diterima di pengadilan dengan ketentuan/syarat membawa surat keterangan tidak mampu dari lurah. Untuk mendapatkan surat keterangan itupun membutuhkan biaya. 
Hal ini pernah ditemukan di lapangan ketika penulis berkunjung ke Pengadilan Agama. Pihak yang berperkara mengatakan bahwa sidangnya ditunda sampai jam sekian. Ternyata waktu sidang yang ditentukan oleh majelis hakim yang menyidangkan suatu perkara sering ditunda (molor). Hal ini pula yang menjadi penyebab advokat kurang mau memberikan jasa hukumnya di Pengadilan Agama karena ketidakkonsistensian waktu dan pelayanan yang berbelit-belit. Oleh karena itu, untuk mewujudkan peradilan yang sederhana, cepat dan biaya ringan serta menjunjung tinggi asas keadilan, dibutuhkan sebuah reformasi penyelesaian perkara yang efektif dan efisien serta menjadikan lembaga peradilan sebagai lembaga yang melayani masyarakat bukannya lembaga yang mau dilayani.

Gambaran pada pendahuluan di atas menarik penulis untuk meneliti secara mendalam tentang penerapan asas hukum yang meliputi asas sederhana, cepat dan biaya ringan terhadap penyelesaian perkara di Pengadilan Agama.

\section{Pemahaman Terhadap Asas Hukum}

Pemahaman terhadap asas hukum dalam pendekatan ilmu hukum merupakan landasan utama yang menjadi dasar atau acuan bagi lahirnya suatu aturan. Pemahaman terhadap asas hukum perlu sebagai tuntutan etis dalam mendalami peraturan perundang-undangan yang berlaku. Asas hukum mengandung tuntutan etis. Dapat dikatakan, melalui asas hukum, peraturan hukum berubah sifatnya menjadi bagian dari suatu tatanan etis.

Asas hukum merupakan unsur penting dan pokok dari peraturan hukum. Pembentukan hukum praktis sedapat mungkin berorientasi pada asas-asas hukum. Asas hukum menjadi dasardasar dan petunjuk arah dalam pembentukan hukum positif.

Keterkaitan erat antara asas hukum dengan hukum itu sendiri tampak dari pendapat yang dikemukakan oleh Mochtar Kusumaatmadja yang menyatakan bahwa hukum itu tidak hanya merupakan seperangkat asas hukum yang mengatur kehidupan manusia dalam masyarakat saja, tetapi juga mencakup lembaga 
dan proses yang diperlukan untuk mewujudkan hukum itu dalam kenyataan.

Asas memiliki pengertian yang berbeda-beda. Asas adalah sesuatu yang menjadi tumpuan berfikir atau berpendapat. Asas dapat juga berarti hukum dasar. Menurut The Liang Gie, asas merupakan suatu dalil umum yang dinyatakan dalam istilah umum tanpa menyarankan cara-cara khusus mengenai pelaksanaannya, yang diterapkan pada serangkaian perbuatan untuk menjadi petunjuk yang tepat bagi perbuatan itu. ${ }^{5}$ Asas juga dapat dimaknai sebagai dasar berfikir atau dasar berpendapat atau dengan kata lain asas merupakan nilai-nilai yang menjadi titik tolak dalam berfikir dan berpendapat. ${ }^{6}$ Adapun Hujibers berpendapat bahwa asas hukum dapat juga disebut pengertianpengertian dan nilai-nilai yang menjadi titik tolak berfikir tentang hukum. Asas-asas itu merupakan titik tolak bagi pembentukan undang-undang dan interpretasi undang-undang tersebut. ${ }^{7}$

Untuk mencari arti dari asas hukum yang paling tepat, kiranya perlu diuraikan pandangan dari para ahli. Berikut ini pandangan para ahli seperti Bellefroid, van Eikema Hommes, dan Scholten tentang arti asas hukum. ${ }^{8}$ Bellefroid berpendapat bahwa asas hukum umum adalah norma dasar yang dijabarkan dari hukum positif dan yang oleh ilmu hukum tidak dianggap berasal dari aturan-aturan yang lebih umum. Asas hukum merupakan pengendapan hukum positif dalam suatu masyarakat. ${ }^{9}$

Eikema Hommes mengatakan bahwa asas hukum itu tidak boleh dianggap sebagai norma-norma hukum konkret, akan tetapi perlu dipandang sebagai dasar-dasar umum atau petunjukpetunjuk bagi hukum yang berlaku. Pembentukan hukum praktis

\footnotetext{
5 The Liang Gie, Teori-Teori Keadilan: Sumbangan Bahan Untuk Pemahaman Pancasila (Yogyakarta: Supersukses, 1982), 10.

${ }^{6}$ Fence M. Wantu, Idee Des Recht: Kepastian Hukum, Keadilan, dan Kemanfaatan (Impelementasi Dalam Proses Peradilan Perdata), (Yogyakarta: Pustaka Pelajar, 20I I), 50.

${ }^{7}$ Fence M. Wantu, Idee Des Recht: Kepastian Hukum, Keadilan, dan Kemanfaatan..., 51.

${ }^{8}$ Sudikno Mertokusumo, Penemuan Hukum Sebuah Pengantar, (Yogyakarta: Liberty, 2009), 5.

${ }^{9}$ lbid.
} 
perlu berorientasi pada asas-asas hukum tersebut. Scholten mengatakan bahwa asas hukum adalah kecenderungankecenderungan yang disyaratkan oleh pandangan kesusilaan kita pada hukum, merupakan sifat-sifat umum dengan segala keterbatasannya sebagai pembawaan yang umum itu, tetapi tidak boleh tidak, harus ada. ${ }^{10}$

Sudikno Mertokusumo berpendapat bahwa asas hukum bukanlah peraturan hukum yang nyata, melainkan pikiran dasar yang umum dan abstrak, atau merupakan latar belakang peraturan yang ada yang terdapat dalam dan di belakang setiap sistem hukum yang terjelma dalam peraturan perundangundangan dan putusan hakim yang merupakan hukum positif dan dapat diketemukan dengan mencari sifat-sifat atau ciri-ciri yang umum dalam peraturan konkret tersebut. Ini berarti menunjuk pada kesamaan-kesamaan tersebut dengan menjabarkan peraturan hukum yang ada menjadi peraturan hukum yang karena menjadi umum sifatnya tidak dapat diterapkan secara langsung pada peristiwa yang nyata. ${ }^{11}$

Memahami asas hukum, perlu dibedakan asas hukum yang objektif dan asas hukum yang subjektif. Asas hukum objektif adalah prinsip-prinsip yang menjadi dasar bagi pembentukan hukum. Asas hukum objektif ini dibedakan atas asas hukum yang bersifat moral dan asas hukum yang bersifat rasional. Asas hukum subjektif adalah prinsip-prinsip yang menyatakan kedudukan subjek hukum dalam hubungannya dengan hukum. Asas hukum subjektif ini ada yang bersifat moral ataupun bersifat rasional, yaitu hak-hak yang ada pada manusia dan menjadi titik tolak pembentukan hukum. Pada asas hukum yang subjektif ini, perkembangan hukum tampak atau terlihat. 


\section{Fungsi Asas Hukum dalam Peraturan Perundang-undangan}

Asas hukum memiliki fungsi yang sangat penting dalam suatu peraturan perundang-undangan. Hal ini sebagaimana yang diungkapkan oleh Paton, sebagai berikut:

"......... the law should be, as far as possible, reduced to a systematic order-hence the search for principle which can afford the ratio legis lying behind a particular rule can be explained, then it is remembered more easily and the teacher tries to Discovery Broad principles that are only implisit in the law". 12

Berdasarkan pendapat dari Paton di atas, maka asas hukum menjadi sarana untuk membuat hukum itu ada, tumbuh dan berkembang sesuai dengan perkembangan masyarakat itu sendiri. Lebih lanjut, Paton menyatakan bahwa asas hukum ini tidak akan habis kekuatannya dengan melahirkan suatu peraturan hukum, melainkan akan tetap saja ada dan melahirkan peraturanperaturan selanjutnya.

Sidharta berpendapat bahwa dalam dinamika kehidupan hukum di dalam masyarakat, asas hukum itu berfungsi sebagai berikut: Pertama, untuk menetapkan wilayah penerapan aturan hukum pada penafsiran atau penemuan hukum. Kedua, sebagai kaidah etis terhadap aturan hukum. Ketiga, kaidah penilai dalam menetapkan legitimasi aturan hukum. Keempat, kaidah mempersatukan aturan-aturan atau kaidah-kaidah hukum. Kelima, menjaga/memelihara konsistensi dan koherensi aturan-aturan hukum.

Dengan demikian, dapat dikatakan bahwa fungsi asas hukum merupakan jembatan penghubung antara peraturan-peraturan hukum dengan cita-cita sosial masyarakat. Melalui asas hukum, peraturan hukum berubah sifatnya menjadi peraturan yang berlaku umum dalam masyarakat. ${ }^{13}$

\footnotetext{
12 G. W. Paton, A Text-Book Of Yurisprudensi, Second Edition, (London: Oxford At The Claredon Press, 1955), 204.

${ }^{13}$ Fence M. Wantu, Idee Des Recht: Kepastian Hukum, Keadilan, dan Kemanfaatan..., 57.
} 


\section{Asas Hukum dalam Peradilan Perdata}

Ada beberapa asas hukum dalam Peradilan Perdata, dimana asas tersebut menjadi pedoman atau dasar yang harus dilaksanakan oleh hakim dalam mengadili suatu perkara di persidangan. Asas-asas hukum tersebut mengatur tentang proses jalannya persidangan yang harus dan wajib dilaksanakan oleh hakim dalam persidangan pengadilan. Asas-asas hukum dalam Peradilan Perdata adalah sebagai berikut:

a. Hakim bersifat menunggu

Asas hukum dalam acara perdata pada umumnya adalah hakim bersifat menunggu. Inisiatif untuk mengajukan tuntutan hak diserahkan sepenuhnya kepada yang berkepentingan. Apakah akan ada proses atau tidak, apakah ada tuntutan pengajuan hak atau tidak terhadap pelanggaran perdata, semua tergantung kepada para pihak yang merasa dirugikan. Yang mengajukan tuntutan hak adalah pihak yang berkepentingan, sedangkan hakim bersikap menunggu datangnya tuntutan hak yang diajukan kepadanya. Hakim sama sekali tidak boleh menolak perkara yang diajukan oleh para pihak ke pengadilan dengan alasan hukumnya tidak ada atau kurang jelas. Sebagaimana ditegaskan dalam Pasal 28 ayat (1) UndangUndang Nomor 4 Tahun 2004 tentang Kekuasaan Kehakiman, bahwa hakim wajib menggali, mengikuti dan memahami nilainilai hukum dan rasa keadilan yang hidup dalam masyarakat. Bagir Manan menyatakan bahwa dalam melaksanakan tugas dan jabatannya, hakim memang harus selalu berfikir dan bekerja menurut kerangka hukum, tidak boleh di luar hukum. Jadi hakim harus memutuskan menurut hukum. Namun demikian, tidak berarti hakim sekedar atau membuat/corong undang-undang. ${ }^{14}$ Ada larangan untuk menolak memeriksa perkara disebabkan anggapan hakim tidak tahu akan hukumnya (ius curid novit). Kalau sekiranya ia tidak dapat

${ }^{14}$ Bagir Manan, Kekuasaan Kehakiman Di Indonesia Dalam UU No. 4 Tahun 2004, (Yogyakarta: UII Press, 2007), 24I. 
menemukan hukum tertulis, maka ia wajib menggali, mengikuti dan memahami nilai-nilai hukum yang hidup dalam masyarakat. Nilai-nilai hukum yang hidup dalam masyarakat mencerminkan perilaku masyarakat dalam kehidupan seharisehari atau hubungan hukum satu dengan lainnya. Jika dalam undang-undang tidak ditemukan hukumnya, maka hukum adat/kebiasaan bisa dijadikan acuan dalam menyelesaikan sebuah perkara yang diajukan ke pengadilan.

b. Hakim bersifat pasif

Hakim dalam memeriksa perkara perdata bersikap pasif dalam arti bahwa ruang lingkup atau luas pokok sengketa yang diajukan kepada hakim untuk diperiksa pada asasnya ditentukan oleh para pihak yang berperkara dan bukan oleh hakim. Hakim hanya membantu para pencari keadilan dan berusaha mengatasi segala hambatan dan rintangan untuk dapat tercapainya keadilan.

Hakim harus aktif memimpin sidang, melancarkan jalannya persidangan, membantu kedua belah pihak dalam mencari kebenaran, tetapi dalam memeriksa perkara perdata hakim harus bersikap tut wuri. Hakim terikat pada peristiwa yang diajukan oleh para pihak (secundum allegata iudicare). ${ }^{15}$

Para pihak dapat secara bebas mengakhiri sendiri sengketa yang telah diajukannya ke muka pengadilan, sedangkan hakim tidak dapat menghalang-halanginya. Hal ini dapat berupa perdamaian atau pencabutan gugatan. ${ }^{16}$ Hakim wajib mengadili seluruh gugatan dan dilarang menjatuhkan putusan atas gugatan yang tidak dituntut atau mengabulkan lebih daripada yang dituntut. ${ }^{17}$

Pengertian pasif berarti bahwa hakim tidak menentukan luas dari pokok sengketa. Hakim tidak boleh menambah atau

\footnotetext{
15 Muh. Daming Sunusi, "Fungsi Hakim Sebagai Sumber Pembentuk Hukum dalam Perkara Perdata Dihubungkan dengan Asas Peradilan Yang Baik", (Disertasi-Program Studi Ilmu Hukum Fakultas Hukum Universitas Padjadjaran, Bandung, 2009), 143.

${ }_{16}$ Pasal I30 HIR, 154 RBg

17 Pasal 178 ayat 2 dan 3 HIR, 189 ayat 2 dan 3 RBg
} 
menguranginya. Akan tetapi, tidak berarti bahwa hakim sama sekali tidak aktif. Selaku pimpinan sidang, hakim harus aktif memimpin pemeriksaan perkara dan tidak sekedar menjadi pegawai atau alat dari para pihak, dan harus berusaha sekeraskerasnya mengatasi segala hambatan dan rintangan untuk dapat tercapainya keadilan. Hakim berhak memberi nasihat kepada kedua belah pihak serta menunjukkan upaya hukum dan memberikan keterangan kepada mereka. ${ }^{18}$ Karenanya dikatakan bahwa sistem HIR adalah aktif, berbeda dengan sistem Rv yang pada pokoknya mengandung prinsip hakim pasif.

c. Asas biaya ringan dan asas sederhana serta asas cepat

Sederhana, cepat dan biaya ringan merupakan asas yang tidak kalah pentingnya dengan asas-asas lainnya yang terdapat dalam Pasal 5 ayat (2) UU No. 4 Tahun 2004 tentang Kekuasaan Kehakiman. Sederhana adalah acara yang jelas sehingga mudah difahami dan tidak berbelit-belit. Proses acara yang terlalu formalitas dalam proses persidangan akan dapat mengurangi sifat kesederhanaan sehingga memungkinkan timbulnya pelbagai penafsiran yang menyebabkan keengganan atau ketakutan beracara di pengadilan.

Pengertian cepat, menunjuk pada jalannya proses persidangan. Dengan proses yang terlalu formalistis, akan dapat menghambat jalannya peradilan dan proses penyelesaian berita acara persidangan. Sedangkan pengertian biaya ringan adalah agar dapat terpikul oleh rakyat pencari keadilan. Sebab dengan biaya yang tinggi akan menyebabkan pihak yang berkepentingan enggan untuk mengajukan tuntutan hak kepada pengadilan. ${ }^{19}$

d. Asas terbuka untuk umum

Sidang pemeriksaan pengadilan pada asasnya adalah terbuka untuk umum, yang berarti bahwa setiap orang

19 Muh. Daming Sunusi, "Fungsi Hakim Sebagai Sumber Pembentuk Hukum...", 148. 
dibolehkan hadir dan mendengarkan pemeriksaan di persidangan. Tujuan dari asas ini tidak lain untuk memberi perlindungan hak-hak asasi manusia dalam bidang peradilan serta untuk lebih menjamin obyektivitas peradilan dengan mempertanggungjawabkan pemeriksaan yang fair, tidak memihak serta putusan yang adil kepada masyarakat. Asas ini dijumpai dalam ketentuan Undang-undang Nomor 4 Tahun 2004 Pasal 19 ayat (1) dan Pasal 20.

Apabila putusan diucapkan dalam sidang yang tidak dinyatakan terbuka untuk umum, berarti putusan itu tidak sah dan tidak mempunyai kekuatan hukum serta mengakibatkan batalnya putusan itu menurut hukum. Di dalam praktiknya, meskipun hakim tidak menyatakan persidangan terbuka untuk umum, tetapi di dalam berita acara dicatat bahwa persidangan dinyatakan terbuka untuk umum, maka putusan yang telah dijatuhkan tetap sah. Secara formal, asas ini membuka kesempatan untuk "social control".

e. Asas susunan sidang dalam bentuk majelis

Pada dasarnya susunan persidangan adalah dalam bentuk majelis. ${ }^{20}$ Pengadilan memeriksa, mengadili dan memutus dengan sekurang-kurangnya 3 (tiga) orang hakim, kecuali undang-undang menentukan lain. ${ }^{21}$ Susunan hakim sebagaimana dimaksud, terdiri dari seorang hakim ketua dan dua orang hakim anggota. ${ }^{22}$ Adapun maksud dari asas susunan sidang dalam bentuk majelis tidak lain untuk menjamin pemeriksaan yang seobjektif mungkin, guna memberikan perlindungan hak asasi manusia dalam bidang peradilan.

Menurut Sudikno Mertokusumo, meskipun asasnya susunan sidang dalam bentuk hakim majelis, namun dalam praktiknya masih banyak perkara-perkara perdata baik

\footnotetext{
20 Pasal I I ayat (I) dan ayat (2) UU No. 48 tahun 2009 tentang Kekuasaan Kehakiman

${ }^{21}$ Pasal I I ayat (I) UU No. 48 tahun 2009 tentang Kekuasaan Kehakiman

22 Pasal I I ayat (2) UU No. 48 tahun 2009 tentang Kekuasaan Kehakiman
} 
declaratoir maupun contradictoir dan juga perkara-perkara pidana baik summier maupun pidana biasa, diperiksa dengan hakim tunggal, di samping ada sidang-sidang dengan majelis juga. Pemeriksaan dengan hakim tunggal ini tetap sah.

Pada umumnya ada kecenderungan untuk mengembangkan asas hakim tunggal. Alasannya adalah untuk mempercepat jalannya peradilan (speedy administration of justice) dan kurangnya tenaga hakim. Selain itu, alasan mengembangkan asas hakim tunggal dalam praktik yang sering terjadi yakni untuk meningkatkan rasa tanggung jawab dari pihak hakim.

f. Mendengar kedua belah pihak

Di dalam hukum acara perdata, kedua belah pihak haruslah didengar dan diperlakukan sama. Bahwa pengadilan mengadili menurut hukum dengan tidak membedakan orang, seperti yang dimuat dalam Pasal 5 ayat 1 Undang-undang Nomor 14 Tahun 1970, mengandung arti bahwa di dalam hukum acara perdata yang berperkara harus sama-sama diperhatikan, berhak atas perlakuan yang sama dan adil serta masing-masing harus diberi kesempatan untuk memberi pendapatnya.

Asas mendengar kedua belah pihak (audi et alteram pertem) dapat berarti bahwa dalam proses peradilan, para pihak yang berperkara harus diperlakukan dan diberi kesempatan yang sama dan adil untuk membela dan melindungi kepentingan yang bersangkutan. Asas ini menghendaki adanya keseimbangan proses dalam pemeriksaan.

Dalam hukum acara perdata, kedua belah pihak yang berperkara harus diperlakukan sama dan tidak memihak. Berkenaan dengan asas mendengar kedua belah pihak, hakim tidak boleh menerima keterangan dari salah satu pihak, tanpa hadirnya pihak lain.

g. Asas tidak ada keharusan untuk mewakilkan 
HIR tidak mewajibkan para pihak untuk mewakilkan kepada orang lain, sehingga pemeriksaan di persidangan terjadi secara langsung terhadap para pihak yang langsung berkepentingan. Akan tetapi, para pihak dapat dibantu atau diwakili oleh kuasanya kalau dikehendakinya. ${ }^{23}$ Dengan demikian, hakim tetap wajib memeriksa sengketa yang diajukan kepadanya, meskipun para pihak tidak mewakilkan kepada seorang kuasa.

h. Asas kebenaran formil yang dicari

Asas ini mengandung makna bahwa dalam perkara perdata yang hendak dicari oleh hakim adalah kebenaran yang hanya didasarkan atas bukti-bukti sah yang diajukan para pihak dalam sidang pengadilan. Jadi asas kebenaran formil diperoleh hanya didasarkan ada bukti-bukti sah sementara. ${ }^{24}$

Pengertian kebenaran formil tidak boleh ditafsirkan sebagai kebenaran yang setengah-setengah, namun merupakan kebenaran yang diperoleh sebagai hasil penjabaran semua fakta dan peristiwa yang terjadi dan diperoleh selama proses persidangan berlangsung. Dalam praktiknya, tidak diwajibkan mencari dan menyelidiki kebenaran dalam proses persidangan. Kebenaran yang dicari adalah kebenaran yang utuh atau bulat yang saling berkaitan dengan kasus yang terjadi di antara para pihak yang berperkara.

Pada dasarnya, dalam hukum acara perdata yang penting adalah tersedianya alat-alat bukti yang sah. Hakim hanya sekedar menerima, meninjau dan menilai bahan-bahan yang disampaikan oleh pihak-pihak yang berperkara. Berdasarkan alat-alat bukti tersebut, hakim akan mengambil keputusan. Contohnya, bila salah satu pihak menunjukkan alat bukti berupa akta autentik, maka hakim wajib percaya dan membenarkan apa yang tertuang dalam akta tersebut, selama tidak ada bukti yang sebaliknya, tanpa perlu pula dengan

${ }^{24}$ Fence M. Wantu, Idee Des Recht: Kepastian Hukum, Keadilan, dan Kemanfaatan..., 25. 
adanya pengakuan dari tergugat tentang hal-hal yang dituduhkan oleh penggugat, maka hakim dapat menjatuhkan putusan untuk kemenangan pihak penggugat.

i. Asas demi keadilan berdasarkan Ketuhanan Yang Maha Esa

Peradilan dilakukan "Demi Keadilan Berdasarkan KeTuhanan Yang Maha Esa". Semua putusan pengadilan di Indonesia harus diberi kepala di bagian atasnya yang berbunyi "in naam des Konings atau atas nama Raja" sebagaimana tertulis dalam Pasal 35 Rv. Kemudian dengan adanya UU No. 1 Tahun 1950 yakni Pasal 1 ayat (2) dan kehadiran UUDar. Nomor 1 Tahun 1951 yakni Pasal 5, kata-kata "atas nama Raja" diganti menjadi "atas nama Keadilan", dan akhirnya dengan adanya UU Nomor 14 tahun 1970 menjadi "Demi Keadilan Berdasarkan Ke-Tuhanan Yang Maha Esa", sebagai penyesuaian dengan Pasal 29 UUD 1945. Hal ini dapat dilihat dengan ketentuan UU Nomor 49 tahun 2009 tentang Peradilan Umum.

Asas peradilan dilakukan demi keadilan berdasarkan keTuhanan Yang Maha Esa, mensyaratkan bahwa hakim dalam proses peradilan tidak hanya bertanggung jawab kepada hukum dan diri sendiri serta kepada masyarakat, tetapi bertanggung jawab juga kepada Tuhan Yang Maha Esa. Selain itu, asas ini juga menjamin agar putusan tersebut mempunyai kekuatan eksekutorial, yaitu kekuatan untuk melaksanakan putusan secara paksa, apabila pihak yang dikalahkan tidak mau melaksanakan putusan dengan sukarela.

j. Putusan harus disertai alasan

Menurut ketentuan Pasal 25 ayat (1) Undang-undang Nomor 4 tahun 2004, segala putusan pengadilan selain harus memuat alasan dan dasar putusan, memuat pula Pasal tertentu dari peraturan perundang-undangan yang bersangkutan atau sumber hukum tak tertulis yang dijadikan dasar untuk mengadili. Alasan-alasan atau argumentasi itu dimasudkan sebagai pertanggungjawaban hakim berkaitan dengan 
putusannya terhadap masyarakat, para pihak, pengadilan yang lebih tinggi dan ilmu hukum, sehingga putusan tersebut mempunyai nilai obyektif. Karena adanya alasan-alasan itulah maka putusan mempunyai wibawa dan bukan karena hakim tertentu yang menjatuhkannya.

\section{Pengertian Asas Peradilan Sederhana, Cepat dan Biaya Ringan}

Berperkara di pengadilan pada dasarnya tidak dikenai biaya. Biaya yang dimaksud dalam asas ini meliputi biaya kepaniteraan dan biaya untuk pemanggilan, pemberitahuan kepada para pihak, dan biaya materai. ${ }^{25}$

Bagi mereka yang tidak mampu membayar biaya perkara, pada dasarnya dapat mengajukan permohonan biaya perkara secara cuma-cuma (prodeo), dengan menyertakan surat keterangan tidak mampu yang dibuat oleh pejabat yang berwenang. Dalam praktiknya, surat keterangan tidak mampu ini cukup dibuat oleh camat di daerah tempat yang berkepentingan tinggal. Pengadilan akan menolak terhadap permohonan biaya perkara secara cumacuma apabila pemohon bukan orang tidak mampu.

Kata biaya ringan dalam asas ini dapat dimaknai sebagai biaya yang serendah mungkin sehingga dapat dipikul oleh rakyat. Sebaliknya biaya perkara yang tinggi akan membuat orang enggan untuk berperkara di Pengadilan.

Asas peradilan cepat, sederhana dan biaya ringan telah diatur dalam Undang-undang Nomor 4 Tahun 2004 tentang Kekuasaan Kehakiman (yang menggantikan Undang-undang Nomor 14 tahun 1970 tentang Ketentuan-ketentuan Pokok Kekuasaan Kehakiman, sebagaimana telah diubah dengan Undang-Undang Nomor 35 tahun 1999 tentang Perubahan atas Undang-Undang Nomor 14 Tahun 1970. Pada Pasal 4 ayat (2) Undang-undang Nomor 4 Tahun 2004 menyatakan bahwa peradilan dilakukan dengan sederhana, cepat dan biaya ringan, selanjutnya dalam Pasal 5 ayat (2) dinyatakan, bahwa pengadilan membantu pencari keadilan dan

\footnotetext{
${ }^{25}$ Fence M. Wantu, Idee Des Recht: Kepastian Hukum, Keadilan, dan Kemanfaatan..., 235.
} 
berusaha mengatasi segala hambatan dan rintangan untuk dapat tercapainya peradilan yang sederhana, cepat dan biaya ringan. Selanjutnya dalam penjelasan Pasal 4 ayat (2) menyatakan, bahwa ketentuan ini dimaksudkan untuk memenuhi harapan para pencari keadilan.

Konsep pengertian sederhana dan biaya ringan hanya dijumpai dalam penjelasan Pasal 4 ayat (2) Undang-undang Nomor 4 Tahun 2004 yang menyebutkan, bahwa yang dimaksud dengan sederhana adalah pemeriksaan dan penyelesaian perkara dilakukan dengan acara efisien dan efektif. Biaya ringan adalah biaya perkara yang dapat dipikul oleh rakyat. Sedangkan yang dimaksud dengan cepat tidak dijumpai dalam penjelasan tersebut. Oleh karena itu, ukuran sederhana, cepat dan biaya ringan didasarkan pada apa yang dirasakan oleh masyarakat atas dasar perlakuan yang wajar dan seharusnya dari aparat penegak hukum baik pada tataran litigasi maupun non litigasi.

Asas sederhana maksudnya adalah proses acaranya jelas, mudah dipahami dan tidak berbelit-belit. Makin sederhana dalam proses beracara di pengadilan, maka semakin baik. Sebaliknya terlalu banyak atau berbelit-belit proses beracara akan semakin sulit dipahami dan akan menimbulkan beraneka ragam penafsiran sehingga kurang menjamin adanya kepastian hukum.

Kata asas cepat dapat dimaknai sebagai proses peradilan yang cepat dan proses penyelesaian yang tidak berlarut-larut yang terkadang harus dilanjutkan oleh ahli warisnya. Terlalu banyak formalitas merupakan hambatan bagi jalannya peradilan. Dalam hal ini bukan hanya jalannya peradilan dalam pemeriksaan di muka sidang saja, tetapi juga penyelesaian dari berita acara pemeriksaan di persidangan sampai pada penandatanganan putusan oleh hakim dan pelaksanaannya. Tidak jarang suatu perkara tertunda-tunda sampai bertahun-tahun karena saksi tidak datang atau para pihak bergantian tidak datang atau minta mundur. Bahkan perkaranya sampai dilanjutkan oleh para ahli warisnya. Maka cepatnya jalannya peradilan akan meningkatkan 
kewibawaan pengadilan dan menambah kepercayaan masyarakat kepada pengadilan. ${ }^{26}$

\section{Penyelesaian Perkara di Pengadilan Agama Manado}

\section{Berdasarkan Asas Peradilan Sederhana, Cepat dan Biaya Ringan}

Ketentuan mengenai asas sederhana, cepat dan biaya ringan diatur dalam Undang-Undang Nomor 19 Tahun 1964, UndangUndang Nomor 14 Tahun 1970, Undang-Undang Nomor 35 Tahun 1999 dan Undang-Undang Nomor 4 Tahun 2004. Pasal 4 ayat (2) UU No. 19 Tahun 1964 memuat pengertian "sederhana" dan "biaya ringan", tetapi tidak ada ketentuan mengenai kata "cepat". Sederhana adalah pemeriksaan dan penyelesaian perkara dilakukan dengan cara yang efisien dan efektif. Efisien berkaitan dengan waktu dan efektif berkaitan dengan cost atau biaya. Dengan demikian, pengertian "cepat" menjadi bagian dari pengertian "sederhana". Sedangkan yang dimaksud "biaya ringan" adalah biaya perkara yang dapat terpikul oleh rakyat.

Bagi pencari keadilan yang tidak (kurang) mampu dimungkinkan berperkara dengan cuma-cuma yang diajukan sesuai dengan syarat dan tata cara yang berlaku dan tidak pernah ditolak pengadilan (selalu dikabulkan). Namun dari segi lain, biaya ringan juga menimbulkan ekses. Karena biaya ringan maka sangat mudah pihak yang berperkara mengajukan upaya hukum, walaupun diketahui atau dapat diduga upaya hukum akan ditolak atau tidak dapat diterima. Berdasarkan pertimbangan tersebut, maka pada pemeriksaan tingkat kasasi atau peninjauan kembali dikenakan pembayaran yang lebih mahal. Dengan semangat yang sama, UU No. 14 Tahun 1970 menjelaskan pengertian "cepat" yaitu tidak diperlukan pemeriksaan dan acara yang berbelit-belit yang dapat menyebabkan proses sampai bertahun-tahun, bahkan kadang-kadang harus dilanjutkan oleh ahli waris pencari keadilan. Sedangkan "biaya ringan" diartikan sebagai biaya yang serendah

${ }^{26}$ Sudikno Mertokusumo, Hukum Acara Perdata Indonesia, Edisi Kelima, (Yogyakarta: Liberty, 1998), 25. 
mungkin sehingga dapat terpikul oleh rakyat. Ini semua tanpa mengorbankan ketelitian untuk mencari kebenaran dan keadilan. ${ }^{27}$

Berperkara di Pengadilan Agama Manado bagi masyarakat tidak mampu dinamakan pembebasan biaya perkara. Menurut ketua Pengadilan Agama Manado, Awaluddin, ada 8 (delapan) perkara yang dibebaskan dari biaya perkara dimana dibiayai oleh Negara melalui dana DIPA Pengadilan Agama Manado pada tahun 2014 yaitu Rp. 12.000.000,- (Dua Belas Juta Rupiah).

Persyaratan untuk menerima pembebasan biaya perkara menurut beliau adalah menunjukkan identitas atau kartu miskin seperti Jamkesmas, Jamkesda, Gakin, Kartu Miskin, dan lain-lain. Persyaratan tersebut sangat memudahkan masyarakat tidak mampu untuk menerima pembebasan biaya perkara di Pengadilan Agama Manado.

Asas "sederhana" berkaitan dengan "acara" atau "beracara". Secara normatif ada ketentuan-ketentuan yang mengatur mengenai cara-cara beracara yang lebih sederhana. Dalam KUHAP didapati ketentuan mengenai pemeriksaan secara cepat dan singkat yang lazim disebut perkara-perkara tindak pidana ringan atau disingkat "tipiring". Dalam "tipiring" kesederhanaan itu antara lain tidak diperlukan surat dakwaan, tidak ada keharusan didampingi advokat. Tetapi, khusus dalam pemeriksaan perkara dengan acara singkat, tergantung pada penuntut umum. Penuntut umum yang menentukan suatu perkara akan diperiksa dengan acara singkat atau acara biasa.

Mengenai perkara perdata, asas kesederhanaan ditentukan juga oleh para pihak yang berperkara. Pihak-pihak yang menentukan apakah akan menempuh penyelesaian secara damai atau meneruskan berperkara. ${ }^{28}$ HIR yang diperuntukkan bagi golongan orang Indonesia asli dimaksukan untuk beracara sederhana dan cepat, berbeda dengan Rv. Misalnya dalam HIR, hakim mempunyai peran aktif dalam beracara termasuk

27 Muh. Daming Sunusi, "Fungsi Hakim Sebagai Sumber Pembentuk Hukum...", 2 I 4.

${ }^{28} \mathrm{HIR}$, Pasal I 30 RBg, Pasal I54 
membantu mencatat gugatan, yang diajukan secara lisan karena pemohon tidak pandai menulis menurut tata tulis resmi. Tidak ada syarat-syarat format gugatan. Suatu gugatan sudah dianggap cukup kalau sudah jelas penggugat dan tergugat, alasan menggugat dan tujuan atau sasaran gugatan. Dalam beracara tidak diharuskan ada pembela, dan berbagai kesederhanaan lainnya.

Pengadilan Agama Manado menyiapkan sarana Pos Bantuan Hukum (Posbakum) untuk membantu para pihak membuat surat gugatan ataupun permohonan. Posbakum dalam menjalankan tugasnya tidak meminta bayaran ataupun uang dari para pihak. Para pihak hanya datang ke kantor Posbakum menyampaikan keinginan mereka sekaligus memberikan keterangan atau data yang diperlukan untuk pembuatan gugatan ataupun permohonan.

Bulan Januari sampai Desember 2012 misalnya, gugatan/permohonan yang memakai jasa bantuan hukum dari Posbakum berjumlah 153 gugatan/permohonan. Hal ini menunjukkan bahwa antusias masyarakat menggunakan jasa Posbakum yang disiapkan bagi masyarakat yang mampu ataupun tidak mampu.

Salah satu alasan adanya Posbakum tersebut di Pengadilan Agama Manado adalah untuk membantu para hakim dalam mempercepat proses pemeriksaan perkara. Jika gugatan yang diajukan oleh para pihak tidak memenuhi semua unsur gugatan yaitu identitas, posita dan petitum maka gugatan tersebut dikembalikan kepada pihak penggugat ataupun pemohon untuk diperbaiki. Setelah adanya Posbakum di Pengadilan Agama Manado sangat membantu proses pemeriksaan perkara sehingga asas cepat dapat dilaksanakan dengan baik.

Pemeriksaan perkara di Pengadilan Agama Manado diupayakan tidak melewati jangka waktu 6 (enam) bulan. Lambatnya proses penyelesaian perkara di Pengadilan Agama Manado menurut Panitera Muda Hukum disebabkan oleh beberapa hal yaitu para pihak yang telah dipanggil secara patut tidak menghadiri sidang perkara yang telah ditentukan. Di 
samping itu penyebab lainnya adalah majelis hakim yang menyidangkan perkara tersebut sedang Dinas Luar sehingga sidang harus ditunda.

Penerapan asas cepat dan sederhana dapat disimpulkan bahwa penyebabnya adalah dari para pihak yang berperkara kurang bersungguh-sungguh untuk menghadiri sidang yang ditentukan. Jika 2 (dua) kali berturut-turut tidak hadir pada sidang yang ditentukan maka putusannya dinyatakan gugur. Hal ini menunjukkan bahwa Pengadilan Agama Manado melalui majelis hakim yang menyidangkan perkara tidak ingin berlarut-larut dalam satu perkara saja. Mengingat banyaknya perkara yang harus disidangkan sementara jumlah majelis hakim hanya terbatas yaitu terbagi menjadi 4 (empat) majelis yang bersidang pada hari Senin, Selasa, Rabu dan Kamis. Penerapan asas ini juga disebabkan oleh hakim sebagai majelis yang menyidangkan perkara sering Dinas Luar sehingga persidangan harus ditunda. Seyogyanya hal ini tidak terjadi ketika hakim yang sedang menyidangkan perkara tidak diberikan Dinas Luar sehingga pemeriksaan perkara itu tidak memakan waktu lama.

Pengadilan Agama Manado di samping harus menerapkan asas sederhana dan cepat juga tak kalah pentingnya adalah penerapan asas biaya ringan. Berdasarkan Surat Keputusan Ketua Pengadilan Agama Manado Nomor W18-AI/057A/HK.00.8/1/2013 tentang Panjar Biaya Perkara dan Biaya/Ongkos Pemanggilan dan Pemberitahuan Jurusita/Jurusita Pengganti pada Pengadilan Agama Manado adalah Mapanget Rp. 80.000,-, Bunaken Rp. 100.000,-, Bunaken Kepulauan Rp. 350.000,-, Pineleng Rp. 80.000,-, Tombulu Rp. 100.000,- sampai Rp. 200.000,-, Kalawat Rp. 80.000,-, Airmadidi Rp. 80.000,-, Kauditan Rp. 90.000,-, Kema Rp. 100.000,sampai Rp. 200.000,-, dan Likupang Rp. 100.000,-

Panjar perkara dalam kota Manado adalah Rp. 65.000,-. Taksir biaya perkara dilakukan di Meja 1 dengan perhitungan untuk perkara cerai gugat biasanya dihitung 3P (tiga kali panggilan untuk Penggugat) dan 4T (empat kali panggilan untuk Tergugat). 
Cerai talak dihitung 4P dan 5T. sedangkan untuk perkara Verzet dihitung 1P dan 2T.

Contoh biaya perkara dalam kota Manado sebagai berikut :

\begin{tabular}{ll} 
Pendaftaran & Rp. $30.000,-$ \\
Proses (ATK) & Rp. 50.000,- \\
Panggilan & Rp. $145.000,-$ \\
Redaksi & Rp. $5.000,-$ \\
Materai & Rp. $6.000,-$ \\
\hline Jumlah & Rp. $236.000,-$
\end{tabular}

Panjar biaya perkara yang disetor ke Bank oleh pihak Penggugat. Pada saat proses pemeriksaan perkara berlangsung panjar biaya perkara yang telah disetor ke Bank habis, maka Majelis Hakim menegur kepada pihak Penggugat untuk menambah panjar biaya perkara tersebut. Majelis Hakim memberikan waktu selama 1 bulan untuk menambah panjar tersebut. Jika dalam waktu tersebut tidak dilakukan, maka Pansek Pengadilan Agama mengeluarkan Surat Keterangan bahwa yang bersangkutan tidak menambah panjar biaya perkara. Berdasarkan Surat Keterangan tersebut ketua Majelis yang menangani perkara tersebut memutuskan untuk coret dari register perkara.

Data di atas menunjukkan bahwa majelis hakim tidak akan meneruskan untuk menyidangkan suatu perkara jika pihak Penggugat tidak menyiapkan biaya perkara sampai pada tahap akhir yaitu pembacaan putusan. Hal ini menunjukkan bahwa jika pihak yang berperkara tidak mampu untuk membayar panjar biaya perkara, maka mereka tidak akan mungkin menerima putusan dan mendapatkan keadilan. Biaya perkara bagi masyarakat tidak mampu untuk tahun 2014 hanyalah bisa digunakan oleh 8 perkara saja. Sementara masyarakat yang tidak mampu berperkara di Pengadilan Agama Manado lebih dari 8 gugatan atau permohonan. Hal inilah yang perlu diperhatikan oleh pemerintah mengenai pembebasan biaya perkara dengan cara 
menambah biaya tersebut pada DIPA Pengadilan Agama Manado sehingga keadilan itu dapat dirasakan oleh masyarakat.

\section{Penutup}

Penerapan asas sederhana dan cepat di Pengadilan Agama Manado dalam hal pembuatan gugatan ataupun permohonan dilaksanakan dengan baik. Salah satu unsur yang membantu adalah dengan adanya Pos Bantuan Hukum (Posbakum) yang berkantor di Pengadilan Agama Manado. Penerapan asas tersebut belum dilaksanakan dengan baik dalam hal penyelesaian perkara. Hal ini disebabkan oleh beberapa alasan yaitu para pihak yang kurang bersungguh-sungguh hadir pada persidangan yang telah ditentukan dan majelis hakim sering menunda sidang dengan alasan Dinas Luar atau cuti.

Biaya berperkara di Pengadilan Agama Manado ditentukan berdasarkan radius atau jarak wilayah pihak berdomisili. Biaya tersebut ditaksir oleh Meja 1 termasuk biaya pendaftaran, pemanggilan para pihak atau saksi, ATK, dan materai. Jika Penggugat adalah termasuk masyarakat tidak mampu dan memiliki kartu miskin maka dapat dikenakan pembebasan biaya perkara. Pembebasan ini pun bisa dilakukan jika dana DIPA untuk hal tersebut masih tersedia. Jika dana DIPA tidak ada maka Prodeo murni yaitu harus membayar biaya perkara. Jika panjar biaya perkara tidak dibayar, maka perkara tersebut tidak bisa diregister.

\section{Daftar Pustaka}

Atmasasmita, Romli. Teori Hukum Integratif-Rekonstruksi Terhadap Teori Hukum Pembangunan dan Teori Hukum Progresif. Yogyakarta: Genta Publishing, 2012.

Gie, The Liang. Teori-Teori Keadilan: Sumbangan Bahan Untuk Pemahaman Pancasila, Cetakan Kedua, Yogyakarta: Supersukses, 1982.

Manan, Bagir. Kekuasaan Kehakiman Di Indonesia dalam UU No. 4 Tahun 2004. Yogyakarta: UII Press, 2007. 
Mertokusumo, Sudikno. Hukum Acara Perdata Indonesia. Edisi Kelima, Yogyakarta: Liberty, 1998.

Mertokusumo, Sudikno. Penemuan Hukum Sebuah Pengantar. Yogyakarta: Liberty, 2009.

Paton, G.W. A Text-Book Of Yurisprudensi, . Second Edition, London: Oxford At The Claredon Press, 1955.

Rasjidi, Lili dan Ira Thania Rasjidi. Dasar-Dasar Filsafat dan Teori Hukum. Bandung: PT Citra Aditya Bakti, 2007.

Sunusi, Muh. Daming. "Fungsi Hakim Sebagai Sumber Pembentuk Hukum Dalam Perkara Perdata Dihubungkan Dengan Asas Peradilan Yang Baik", Disertasi-Program Studi Ilmu Hukum Fakultas Hukum Universitas Padjadjaran, Bandung, 2009.

Wantu, Fence M. Idee Des Recht: Kepastian Hukum, Keadilan, dan Kemanfaatan (Implementasi Dalam Proses Peradilan Perdata). Cetakan Pertama, Yogyakarta: Pustaka Pelajar, 2011.

Undang-Undang Nomor 4 Tahun 2004 tentang Kekuasaan Kehakiman

Undang-Undang Nomor 48 Tahun 2009 tentang Kekuasaan Kehakiman

Undang-Undang Nomor 50 Tahun 2009 tentang Pengadilan Agama 